Semina $\square \quad \mathrm{Nr} 13$

Scientiarum 2014

s. $184-189$

DOI: http://dx.doi.org/10.15633/ss.692

\title{
Matrix i Kartezjusz
}

Jacek Gurczyński, C: |>Czym jest wirtualność Matrix jako model rzeczywistości wirtualnej, wyd. UMCS, Lublin 2013, ss. 259

Dr Jacek Gurczyński jest pracownikiem w Zakładzie Logiki i Metodologii Nauk na Wydziale Filozofii i Socjologii UMCS w Lublinie. Do jego obszaru zainteresowań należy problematyka związaną z rzeczywistością wirtualną oraz z problemem emocjonalnej reakcji na fikcje ${ }^{1}$. Jego książka $C: \mid>C z y m$ jest wirtualność Matrix jako model rzeczywistości wirtualnej porusza kwestie związane z rzeczywistością wirtualną i stanowi próbę nakreślenia ontologii tejże rzeczywistości. Grono odbiorców tej pozycji mogą stanowić nie tylko osoby powiazane z filozofią, ale i też pasjonaci bez głębszego przygotowania filozoficznego.

Książka Jacka Gurczyńskiego została podzielona na dwie części. Pierwsza część zajmuje się wątkami filozoficznymi, które można odnaleźć w filmie Matrix. Ta część pracy wychodzi niejako od filmu w kierunku filozofii, starając się przybliżyć różne interpretacje pojawiających się wątków w dziele braci Wachowskich. Sam film nie stanowi przedmiotu rozważań autora, lecz ma za zadanie lepiej unaocznić wybrane cechy charakterystyczne środowiska wirtualnego. Powodem, dla którego autor wybrał film, który sam określa jako „wyprodukowany przez komercyjną maszynę Hollywood"2, jest dość prosty - obraz ten wywołał duże zainteresowanie filozofią i okazał się nadzwyczaj popularny. Autor przekonuje, że

1 Informacje zaczerpnięto $\mathrm{z}$ wydziałowej strony autora książki dostępnej pod adresem filozofia.umcs.lublin.pl/en/zaklad-logiki-i-filozofii-nauki/jacek-gurczynski.

2 J. Gurczyński, C: $\mid>C z y m$ jest wirtualność Matrix jako model rzeczywistości wirtualnej, Lublin 2013, s. 19. 
zamknięcie filozofii tylko w kręgu akademickim tylko ją wyjaławia i oddala od potoczności, mimo że powinna ona przenikać do całego społeczeństwa. Matrix jest dziełem osobliwym dlatego, że wzbudził ,[...] zainteresowania problemami filozoficznymi - metafizyka, ontologia, epistemologia, aksjologia, antropologią"3 i jest dziełem popkultury, a więc jest bliżej ludzi niż „akademicka” filozofia. Posłużenie się obrazem filmowym ma na celu zainspirować do stawiania pytań i znalezienia inspiracji do dyskusji. Autor w pierwszych rozdziałach zajmuje się porównaniem Kartezjańskiego sceptycyzmu z sytuacja przebywania w symulacji Matrixa. Zauważa on, że niepewność w rozróżnieniu snu od jawy u Kartezjusza wynika głównie z tego, że jego pojęcie snu nijak nie ma się do faktycznego stanu snu, za to ma wiele cech wspólnych z symulacja i zanurzeniem w rzeczywistość wirtualną. Autor zwraca uwagę jednak, że Matrix ma z jednej strony charakter intersubiektywny - charakterystyczny dla symulacji, ale także ma w sobie coś ze świata sennego - wola ma siłę sprawczą. Ostatecznie jednak autor pokazuje, że Matrix jest symulacja, a sprawcza moc procesów wolitywnych jest jedynie incydentalna i zwiąana ze sposobem komunikacji między Matrixem (systemem VR) a użytkownikiem. Kolejne rozdziały pracy poruszaja temat Matrixa jako hipotezy sceptycznej. Ową hipotezą sceptyczną jest udzielenie negatywnej odpowiedzi na pytanie, czy wiem, że jestem (bądź nie) aktualnie w symulacji Matrixa. Autor przytacza ciekawą argumentację starająca się odrzucić taki sceptycyzm, jednocześnie zwracając uwagę na pewne problemy związane $\mathrm{z}$ niezrozumieniem stanowiska sceptycznego. Następnie poruszony jest temat doświadczenia myślowego H. Putnama o mózgu w naczyniu, który stanowi podstawę do dwóch kierunków rozważań: a) czy dałoby się wyrazić to, że jesteśmy w Matrixie, oraz b) jaki status maja przekonania nabyte w świecie wirtualnym. Problem prawdziwości przekonań $\mathrm{w}$ symulacji został przedstawiony bardzo ciekawie. Obydwa stanowiska zostały dobrze scharakteryzowane nie tylko z poziomu

3 Tamże, s. 20. 
osoby przebywającej wyłącznie w symulacji, ale także osoby, która ma możliwość możliwość swobodnej przejścia między światami rzeczywistym i wirtualnym. Ciekawym problemem zaznaczonym w rozdziale jest kwestia, gdzie istnieje osoba, która całe życie była podłączona do symulacji pokroju Matrixa i jak wyjście z systemu wirtualnego zmienia status osoby. „Rozważmy najpierw, mówi Łukasiewicz, przypadek kogoś, kto - jak Neo przed spotkaniem Morfeusza - od urodzenia przebywa w Matrixie i wszelkie akty intencjonalne spełnia wyłączeni tam, w obrębie pewnej symulacji komputerowej. W takiej sytuacji w pojemniku z ciałem żadna osoba nie istnieje. [...] Nieco inaczej przedstawia się sytuacja w przypadku kogoś, kto - jak na przykład Trinity - spełnia akty intencjonalne zarówno w świecie wirtualnym, jak i pozawirtualnym"4. Problem ten jest rozważany w tekście w odniesieniu do spójności przekonań świata wirtualnego i realnego. Autor zauważa, że istnieją dwie drogi rozwiąania problemu - można rozumować, że osobie w świecie wirtualnym oraz realnym przysługują różne, niewykluczające się nawzajem własności, lub że osoba w świecie wirtualnym jest inną od tej ze świata rzeczywistego, a jedynym ich wspólnym elementem jest to samo biologiczne ciało i mózg. Kolejne rozdziały są nie mniej ciekawe i skupiają się wokół Matrixa jako hipotezy metafizycznej, to znaczy takiej, która może mówić nam coś o świecie. Autor powołuje się na D. Chalmersa i przedstawia jego tok rozumowania. Wszystko to po to, aby w kolejnych rozdziałach móc przyglądnąc się, jak koncepcja umysłu rozszerzonego A. Clarka ma się do partycypacji w rzeczywistości, która może być wirtualna. Zwięźle, ale dokładnie, autor opisuje ideę umysłu rozszerzonego i zakorzenionego oraz pokazuje, że środowisko wirtualne, jeżeli zachowuje pewne cechy (m.in. opór wobec działań, możliwość wchodzenia w interakcje), może stanowić przestrzeń dla ucieleśnionego umysłu. Ciekawym problemem pozostawionym na koniec pierwszej części książki jest pytanie, czy my sami i nasza rzeczywistość nie jesteśmy tylko symulacją two-

4 Tamże, s. 75. 
rzoną aktualnie przez naszych następców. Koniec części pierwszej stanowi podsumowanie przedstawionych treści.

Druga część skupia się przede wszystkim na „sformułowaniu i uzasadnieniu jasnej i wyraźnej definicji rzeczywistości wirtualnej oraz wypracowaniu autorskiego projektu zarysu ontologii wirtualności". W tym celu autor w pierwszych rozdziałach części drugiej skupia się na określeniu, jakie własności przysługują pojęciu wirtualności. Omówiona jest także historia początków wirtualności, których autor doszukuje się już w 1929 roku. Jacek Gurczyński zwraca uwagę, że „[...] [o] ile druk i radio mówia, scena i ekran pokazuja, o tyle rzeczywistość wirtualna ucieleśnia"5. Zwrócona jest także uwaga na dwa zakresy, w przypadku których używa się określenia „wirtualność” - szeroki - dowolne interaktywne środowisko cyfrowe, oraz waskie - system umożliwiajacy zanurzenie zmysłowe; sam autor zaznacza, że kolejne rozważania są prowadzone w odniesieniu do wirtualności w ujęciu szerokim. W kolejnych rozdziałach stawia sobie za cel ustalenie cech rzeczywistości wirtualnej. Zwraca on uwagę na dwuczłonowość tego pojęcia, po czym próbuje wyabstrahować własności, które przedstawiają sobą pojęcie „rzeczywisty” oraz „wirtualny”, w taki sposób, aby złożenie tych określeń nie było oksymoronem. Następnie dokonuje analizy cech charakterystycznych przysługujacych rzeczywistości wirtualnej w oparciu o książkę M. Heima The Metaphysics of Virtual Reality. Podaje on zestaw cech, które - choć nie stanowia kryterium definicyjnego - wyznaczają pewien zakres pojęć silnie związanych z rzeczywistością wirtualna. Są to: symulacja, interaktywność, sztuczność, immersja, teleobecność, zanurzenie pełnocielesne, komunikacja sieciowa. Zaznacza jednocześnie, że nie jest to zestaw kryteriów definicyjnych, ale razem pojęcia te w pewien sposób wyznaczaja to, co nazwać można rzeczywistością wirtualna. W kolejnym rozdziale analizowana i poddana krytyce jest teoria matryc M. Ostrowickiego. Matryca w tej teorii byłaby jakaś przetwarzajacca informacje struktura, której fizyczna „implementacja”

5 Tamże, s.115. 
byłaby różna dla różnych obiektów, roślin, zwierząt czy dzieł sztu$\mathrm{ki}^{6}$. Tematyce teorii macierzy poświęcono stosunkowo dużo miejsca w recenzowanej pozycji. Kolejny rozdział koncentruje się na ustaleniu różnic między fikcją a wirtualnością. Autor stara się podać cechy obiektów fikcyjnych. W swoich rozważaniach skupia się na przedstawieniu i analizie poglądów A. Meinonga oraz R. Ingardena. Oprócz znajdowania różnic między obiektami wirtualnymi i fikcyjnymi autor zwraca także uwagę na podobieństwa występujące między nimi. Na końcu przedstawia swój zarys ontologii rzeczywistości wirtualnej. Opisuje różnice między rzeczywistością analogową a cyfrowa; ukazuje, że niezależnie od natury rzeczywistości powstanie światów wirtualnych tworzy nową przestrzeń rzeczywistości jak też dostarcza cennych wniosków na temat ontologii świata realnego.

Książka Jacka Gurczyńskiego bardzo ciekawie przedstawia temat rzeczywistości wirtualnej, czerpiąc inspiracje z filmu Matrix i podbudowujacc to rzetelna wiedza z zakresu filozofii. Pozycja ta stanowi dobra lekturę dla każdego, kto jest zainteresowany ontologia świata wirtualnego, zaś bogactwo przypisów i cytowań zasługuje na wyróżnienie, tak jak i format wydania i czytelne czcionki. Niestety, znalazło się parę błędów literowych, które nie wpływaja w istotny sposób na odbiór dzieła, jednak drażnia, jak chociażby pomyłki w nazwie kontrolera ruchu firmy Microsoft o nazwie Kinect (a nie kinnect). Dodatkowo niektóre watki sa w moim odczuciu za szybko ucinane, jak np. myśl ze strony 136: „źródła interaktywności środowiska wirtualnego należy upatrywać w tym, że u jego podłoża tkwią procesy obliczeniowe, w tym, że jest to środowisko cyfro-

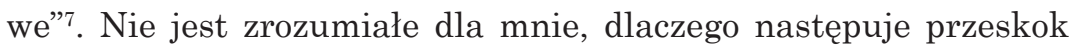
myślowy, że tylko środowisko cyfrowe może być źródłem interaktywności wirtualnej, szczególnie przy tezie, która pojawia się na łamach książki, że (na podstawie teorii emergencji) warstwa obliczeniowa jest warstwa, na której ufundowane sa warstwy wyższe (np. warstwa rzeczywistości wirtualnej), ale one z kolei nie określa-

6 Tamże, s. 160.

7 Tamże, s. 136. 
ją warstwy niższej, a już na pewno nie zacieśniają swojej realizacji tylko do warstw cyfrowych.

Jednak mimo tych wątpliwości odnośnie do niektórych fragmentów książki należy z cała pewnością oddać szacunek autorowi za istotny wkład w przedstawienie i analizę bardzo ciekawego tematu wirtualności i tematów pokrewnych, zaś wszystkich czytelników zachęcić do lektury.

Piotr Gumułka 